\title{
Legal Aspects of Safety Management in Civil Aviation
}

\author{
Michał Lutek \\ Faculty of Law and Administration, University of Warsaw, Poland \\ lutek.michal@gmail.com
}

\begin{abstract}
The article aims to show selected issues related to safety management system with particular reference to its legal aspects. It is composed of seven parts. The first one outlines the general overview on the problem of aviation safety. In the following passage, the substance of safety management in civil aviation is presented. The third part describes key factors determining safety in aviation. In the fourth section, selected issues regarding international regulations concerning safety management systems are discussed with reference to Chicago Convention and Annex 19 which established detailed arrangements for safety management. Subsequently, the author describes the EU legislation related to subject matter as well as major institution in charge of ensuring safety like the European Aviation Safety Agency. The last but one part refers to some legal aspects of safety management in civil aviation in Polish law. The summary contains conclusions drawn from the analysis of the both international and Polish regulations.

Purpose - The paper's main purpose is to present legal framework of aviation safety management at the level of international, European and Polish law. The author also investigates the role of legal regulations in the process of keeping aviation safe with reference to other factors which have a negative influence on aviation safety.

Design/Methodology/Approach - A comprehensive analysis of legislation was conducted along with a literature review, including international publications focused both on the area of management and law. The reference list was selected in order to show an objective and impartial approach to the subject matter.

Findings - The laws regarding safety management in aviation are subject to harmonization but we can observe that the regulations are becoming more and more technical and complex.

Research limitations/implications - The limitations of this paper lie in the lack of review of the studies of practical part of the safety management system regulations.

Practical implications - The review shows a profound review of legislation which may be used by both managers and lawyers from the aviation industry. Moreover, some statistical data is provided in order to emphasize the importance of safety management in the world.

Originality/Value - The article presents the analysis conducted at three levels of legal regulations i.e. international, European and local (Polish) which is the best way to show similarities and point out differences.
\end{abstract}

Keywords - safety management, aviation management, safety management system, aviation law, civil aviation

\section{Introduction}

The development of civilization that is possible, inter alia, thanks to the emergence of new techniques is reflected in many areas of life. Therefore, it can also be observed in transport. In recent years, it even manifests itself in the more and more common

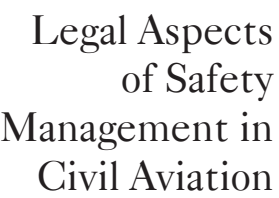
Civil Aviation 
IJSR 7

use of unmanned aerial vehicles that were originally used for military tasks. However, nowadays they are widely used for commercial purposes.

There are, however, situations in which technological progress does not go hand in hand with safety. An example that illustrates very well this phenomenon was the use of Concorde, the supersonic passenger aerial vehicle in the regular air navigation service. The first commercial flight of this aircraft took place on 21 January 1976 but as soon as in early 2003 all aerial vehicles manufactured by the British-French consortium were retired from service (Johnstone-Bryden, 2018). One of the most tragic events in the history of the supersonic passenger aviation was the disaster of the Air France Flight 4590 that took place on 25 July 2000. After the crash, E. Giemulla (an aviation expert) referred to the supersonic jet as a "flying time bomb" (Cause of Concorde Crash Could Take 18 Months, 2018).

According to the Aviation Safety Network, 2017 was the safest year in aviation history as only 10 fatal accidents happened resulting in the death of 44 persons (ASN data show 2017 was safest year in aviation history, 2017). There are numerous factors leading to the above-mentioned situation. One of them is integrated approach to the safety management. The commitment of the international community to the issues discussed was expressed in such a way that the International Civil Aviation Organization (ICAO) adopted Annex 19 entitled "Safety Management".

The present article aims to introduce key questions related to legal aspects of safety management in civil aviation. The role of the international institutions, mainly at the level of the European Union, that are responsible for developing the appropriate standards will be presented as well.

\section{Substance of safety management in civil aviation}

While starting to consider the substance of safety management in civil aviation, the fundamental distinction between two seemingly similar terms - "aviation safety" and its "security" - should be made. The difference between "safety" and "security" should be clarified. The relevant feature that differentiates these two terms is the type of danger that may occur during flights. Referring to the legal definition included in Annex 19 to the Convention on International Civil Aviation signed on 7 December 1944 and adopted in Chicago (hereinafter referred to as Chicago Convention) (Convention on International Civil Aviation, 1944) safety shall be understood as "the state in which risks associated with aviation activities, related to, or in direct support of the operation of aircraft, are reduced and controlled to an acceptable level" (Annex 19 Safety Management, 2013). This approach shall be compared with the definition of the security included in Annex 17 that should be considered in terms of security against acts of unlawful interference. The mentioned aim will be achieved "[...] by a combination of measures and human and material resources" (Annexes 1-18, 1974). The presented definitions were included in Annexes constituting the instrument that the ICAO Council uses in order to adapt the provisions of the Convention to ever-changing realities. Annexes are not mandatory. State parties to the Chicago Convention are not obliged to bind themselves with the regulations of Annexes since the ICAO Council adopted them in the so-called contracting-out system. It means that the State that does not consent to 
bind oneself with the rules set out in the given Annex but withdraws in full or in part from the application of the regulation by making unilateral statement. However, it must be expressly stressed that the mentioned action has no influence on the legal relations between the organization and other States. At present, the ICAO Council has adopted 19 Annexes. In addition, many manuals that set out technical framework of procedures and are designed to help for interpretative purposes have been issued (Miszczyk-Suchanek, 2017).

After having explained the difference between the terms "safety" and "security", the reference to the term "safety management" should be made. Klich defines it as integrated (systematic) approach to solve the problems related to the flight safety at the international and national level as well as at the level of aviation organizations (Klich, 2010). The "safety management system" is a term that is equally common both in scientific studies and in legal documents. Its legal definition constitutes the part of the aforementioned Annex 19 to the Chicago Convention. In light of Annex 19, the mentioned system shall be understood as a systematic approach to safety management including the indispensable elements: organizational structure, extent of responsibility, policy and procedures (Annex 19 Safety Management, 2013).

In the following chapters the chosen aspects of safety management in civil aviation, viewed from the angle of the international, European and national law, will be discussed.

\section{Factors determining safety in civil aviation}

The complexity of the aviation industry requires numerous factors to be taken into consideration in the process of ensuring safety of the operation. There are several major considerations that usually have a negative impact on safety of the flight, subsequently leading to the air crash or a serious damage. They can be divided into 3 groups:

1. Human error;

2. Aircraft malfunction or poor airplane maintenance;

3. Sabotage (acts of unlawful interference).

The main objective of safety management is to ensure a systematic management approach in order to control danger in the area of aviation operations. The model solution should consider the idiosyncrasy of the organizational structure as the responsibility for safety of the operation should be present at different levels (Yeun et al., 2014). Research shows that according to organizations, an adequate safety management system plays a less important role than employees' safety responsibilities (Gill and Shergill, 2004). It is very important, especially in the times of more and more reliable aircrafts and technological solutions. Human factor is the most vulnerable one in the process of ensuring safety of the flight. Under the term "human factor" we can identify three areas of concern. The first one is the lack of experienced personnel, next the authors emphasize the importance of fatigue issues and proper work practices, the last one can be described as airline management and culture (Salas and Maurino, 2013).

As for the cultural differences in the organization, they may influence the safety of the flight. To show the correlation between the mentioned aspects, we can refer to the air crash of Korean Air Flight 801. Both pilots were Korean, one of them, even though he was aware of the upcoming tragedy as they were flying at a very low altitude, "failed to
Legal Aspects of Safety

Management in Civil Aviation 
IJSR 7

challenge the captain" (Kumaravadivelu, 2008). According to the investigators, the reason for such a behavior was Korean's attitude towards questioning the authority, the co-pilot was convinced that his role is to obey the rules which turned out to have a dramatic effect.

When it comes to the model of safety management system in aviation, it has undergone a significant transformation from best practices to regulatory requirement (Yeun et al., 2014). The change of the approach to the subject matter showed the need to create a legal framework which addressed all the issues in a structured way. Legal regulations play a really important role in keeping aviation industry free from accidents as they set certain standards which have been worked out based on previous occurrences and notifications.

\section{International regulations governing safety management in civil aviation}

International community places special importance on safety matters in many areas, in civil aviation as well. At the level of the international law under Article 44 (a) of the Chicago Convention, the ICAO is the entity to be held responsible for ensuring safe and appropriate development of the international civil aviation in the world. Norms and recommendations in form of Annexes devised by ICAO should be taken into account by the national legislators in the process of lawmaking (Luczak, 2016). By adopting Annex 19 on 25 February 2013 that comprehensively puts safety management in legal framework, ICAO displayed the systematic approach to the discussed issues. Its adoption caused also the necessity of introducing changes in other Annexes that indirectly refer to the discussed issues. Now they will be mentioned. To them belong, inter alia, Annex 1 governing personnel licensing, or Annex 8 touching upon the issue of airworthiness of aircraft.

Norms and recommendations for the procedure that are stipulated in Annex 19 were introduced in order to promote the process of safety management in States parties to the Chicago Convention. One of the key issues points out to the necessity of introducing State Safety Programme in Civil Aviation at the level of state legislation. As it was noted in the introduction to this Act,

[...] State Safety Programme in Civil Aviation aims mainly at integrating State activities related to safety management in the area of State legislation, policy and objectives as well as safety promotion and control over safety management systems exercised by entities conducting economic activity (Krajowy Program Bezpieczeństwa w Lotnictwie Cywilnym, 2016).

Safety management system should be based on the following principles:

1. Safety policy;

2. Risk management;

3. Safety assurance;

4. Safety promotion (Luczak, 2016).

The first of the aforementioned foundations refers to the necessity of establishing appropriate methods and procedures that are adopted into the activities carried out by entities that are required to ensure safety. The State parties to the Chicago Convention 
are bound with the obligation to devise their own safety programmes that will make it possible to achieve "acceptable level of safety performance".

The next element consists of such aspects as potential risk identification along with risk assessment and minimization (Luczak, 2016). The effective functioning of the State Safety Programme in Civil Aviation depends mainly on the appropriately functioning safety management system in aviation organizations. At present, the obligation to implement and maintain such a system lies, among others, with air operators that manage certified airports or with the aviation training organizations. However, the aim is to place this obligation on the widest possible group of entities, including Continuing Airworthiness Management Organization. The purpose of the penultimate of the mentioned principles is to verify the results achieved in the course of safety management and to increase them continuously. The bodies responsible for it verify previously intended effects by reference to the indicators. As a result of the analysis of the risk and incidents that occurred, the entities responsible for it introduce changes aiming at eliminating similar incidents in the future, ergo at increasing the safety level in an organization. Such an activity may only be possible if the person responsible for the adjustment of procedures possesses knowledge of the given incident. Just culture, prevalent in aviation, facilitates informing about hazardous incidents. The opinion that safety of civil aviation is the desired merit and that such safety is possible to achieve by means of reporting by the given bodies their own mistakes made in the course of conducting aviation operations should be considered the foundation of just culture. Entities making the report are not held responsible for it. At the European level it is ensured by the Regulation (EU) No. 376/2014 of the European Parliament and of the Council of 3 April 2014 on the reporting, analysis and followup of occurrences in civil aviation (EUR-lex.europa.eu, 2014). The last point is safety promotion which is implemented chiefly by training the personnel responsible for safety in the given organization. With respect to the personnel, according to ICAO, the main emphasis should be placed primarily on two individuals: on the accountable manager and safety manager (Łuczak, 2016). The former will be accountable to the appropriate authority that operates in air traffic control administration, whereas the safety manager shall be liable towards the accountable manager.

ICAO provides guidelines on safety management in safety management manual (Safety Management Manual, 2013). In respect of good practices concerning airports it is worth referring to the document of ICAO 9774 - Manual on Certification of Aerodromes.

In case of Member States of the European Union (EU), legislation adopted at the EU level plays an incredibly important role because, in the majority of cases, it stipulates the law applicable in Member States. The following section will outline some of the legal issues relating to safety management in the legislation of the EU.

\section{Legislation of the European Union concerning safety management}

The European Union commits itself to the great extent to projects that concern raising the level of safety in civil aviation. Additionally, the Community's action sometimes goes even beyond it. An example of such an action is the international programme Transport Corridor Europe-Caucasus-Asia (TRACECA). Its purpose is to develop economic
Legal Aspects of Safety

Management in Civil Aviation 
IJSR 7

relations and transport between Europe and Asia (Bujanowski, 2016). For a long time, questions concerning civil aviation had been regulated at the international level at which the principles of national sovereignty were considered to be one of the key rules. The year 1977 was an important turning point in the development of the European legislation governing civil aviation, because at that time working group responsible for researching into the issue of air transport in the European Community was set up (Coman-Kund, 2018). From that moment on, the EU developed a well-functioning comprehensive legal system. The functioning of this system is also possible thanks to the existence of the specialized agency of the European Union that is accountable for air traffic safety in the EU, namely the European Aviation Safety Agency (hereinafter referred to as EASA). EASA was established under Regulation (EC) No. 216/2008 of the European Parliament and of the Council of 20 February 2008 on common rules in the field of civil aviation and establishing a European Aviation Safety Agency, and repealing Council Directive 91/670/EEC, Regulation (EC) No. 1592/2002 and Directive 2004/36/EC (hereinafter referred to as Regulation No. 216/2008) (EUR-lex.europa.eu, 2008). In Article 17 of the Regulation 216/2008 it is stipulated that the purpose of EASA activity is to: "ensure the proper functioning and development of civil aviation safety".

With regard to the safety management system, the reference to implementing regulations that to some extent follow the approach of Annex 19 to the Chicago Convention should be made (Luczak, 2016). Provisions regulate, in greater detail, the safety management system in many different entities.

The air operator should be pointed out as one of the fundamental elements of the civil aviation system. Safety management requirements for air operators were specified in Annex IV to the Regulation (EC) No. 216/2008 of the European Parliament and of the Council. In relation to the above-mentioned Regulation, the implementing act constitutes Commission Regulation (EU) No. 965/2012 of 5 October 2012 laying down technical requirements and administrative procedures related to air operations pursuant to Regulation (EC) No. 216/2008 of the European Parliament and of the Council (hereinafter referred to as Regulation 965/2012) (EUR-lex.europa.eu, 2012). In its light, the operator, that is a natural or legal person operating an aircraft, is required to implement and maintain safety system that complies with determined standards. Above all, an air operator is required to determine the scope of responsibilities concerning safety, in particular to appoint the accountable manager. Secondly, for entities that operate aircrafts, dangers caused by the operation should be specified, assessed and finally, actions should be taken in order to minimize the risk. In addition, the safety management system should encompass the description of the policy on safety implemented by the given operator. Furthermore, an operator is required to have qualified personnel that has been trained to perform assigned tasks.

In case of operators that are mainly air carriers, the balance between procedures created to guarantee a high level of safety and between the costs of their implementation has to be found. Naturally, air carriers' main objective is to make profit, but it shall not be done at the expense of the safety of passengers. However, it should be remembered that the comprehensive system for aviation safety management is not solely limited to the operators of aircrafts. The European regulation governs also procedures implemented in training agencies, aircraft technology, airports and air traffic services. The aforementioned 
implementing regulations that are non-legislative acts of the European Commission include many technical requirements concerning the system of the civil aviation safety management. Apart from the Regulation 965/2012, the Commission Implementing Regulation (EU) No. 1035/2011 of 17 October 2011 laying down common requirements for the provision of air navigation services and amending Regulations (EC) No. 482/2008 and (EU) No. 691/2010 should be mentioned. The European regulations referring to the discussed issues that concern entities providing air traffic services are related to the conditions presented by the European Organization for the Safety of Air Navigation (Łuczak, 2016) (hereinafter referred to as Eurocontrol). Eurocontrol issued a few Safety Regulatory Requirements aiming to increase the level of safety in member states. One of them is ESARR3 which addresses the use of safety management systems by Air Traffic Management services (Cepin and Bris, 2017).

While considering Community standards, the European Safety Programme in Civil Aviation should be mentioned. It was presented in the communication from the European Commission before the European Council and the European Parliament in October 2011 (COM/2011/670 final, 2011). The programme should be the answer to requirements introduced by ICAO within the national safety programme. Its aim is to identify priorities of the EU in the field of aviation safety as well as to specify measures necessary for their implementation. Pilot training regarding the use of the latest technologies is mentioned, among others, as one of the priorities (Goudou, 2009).

\section{Chosen legal aspects of safety management in civil aviation in Polish law}

Poland is one of 52 states that on 7 December 1944 attended the Chicago Conference. The Chicago Convention was signed by Poland in 1958. This international agreement was subsequently ratified and it is the source of the universally binding law. The Annexes form an integral part of the Chicago Convention, including Annex 19 that governs the analyzed issues. Owing to the fact that international legal standards have been discussed in the third point, I will only focus on giving the example of their implementation in the national legal order.

Żylicz points out that State parties are bound to cooperate on standardizing the provisions of air navigation (Żylicz, 2011). The Republic of Poland takes such action by introducing references to international provisions into the national law. It is observed, inter alia, in Article 69, paragraph 3, point 3 which imposes on the airport managing body the obligation to have "[...] safety management system at the airports - to the extent required by international provisions".

\section{Conclusions}

Safety management in civil aviation constitutes an extremely important question owing to the fact that this means of transport is exposed to dangers coming from many sources. According to the statistics, the probability of death in an air disaster amounts to 1 in 10 million for international flights in the "industrialized" First World, e.g. Europe (Williams, 2011). In spite of this fact efforts should be made in order to achieve the complete reduction of danger. 
IJSR 7

Because of the complexity of regulations, that are often very technical, their harmonization is a long-lasting process. It should be also noted that the provisions on safety management systems, contrary to a common tendency in lawmaking, are becoming more and more complicated. This also causes that complying with the regulation is more difficult throughout the world.

Finally, the question should be asked whether the safety management system functions well in practice. One could even claim that the comprehensive regulations, both at the international and European level, have led to the increase in the safety level in civil aviation. The integrated approach, that takes into account wide range of entities, has caused that control and oversight are performed at many levels what increases the probability of eliminating dangerous factors. The most important task nowadays is to find a way to measure the effectiveness of the implemented regulations. In general, we can notice a visible decrease in the number of aviation accidents, but we need to develop a tool to assess how efficient the safety management system is. Traditional methods such as auditing do not seem to be sufficient for this particular aim (Yeun et al., 2014). Although there were several attempts to find a more adequate method, e.g. the INDICATE model, the problem of measuring the effectiveness is up-to-date.

One of the Wright brothers - Wilbur - an aviation pioneer once said, "In flying I have learned that carelessness and overconfidence are usually far more dangerous than deliberately accepted risks". Bearing that in mind, international community should strive to identify as many risks as possible and develop coherent regulations enabling eliminating all of them.

\section{References}

Annex 19 Safety Management (2013), $1^{\text {st }}$ ed. (e-book) International Civil Aviation Organization, available at: https://www.casa.gov.au/file/157236/download?token=uZzL-kPo (accessed: 10 June 2018).

Annexes 1-18 (1974). $1^{\text {st }}$ ed. (e-book) International Civil Aviation Organization, available at: http:// www.icao.int/documents/annexes_booklet.pdf (accessed: 10 June 2018).

ASN data show 2017 was safest year in aviation history (2017), available at: https://news.aviationsafety.net/2017/12/30/preliminary-asn-data-show-2017-safest-year-aviation-history/ (accessed: 10 June 2018).

Bujanowski, M. (2016), Bezpieczeństwo lotnictwa cywilnego. Aspekty wspólpracy międzynarodowej, Wydawnictwo Naukowe Scholar, Warszawa.

Cause of Concorde Crash Could Take 18 Months (2018), available at: https://abcnews.go.com/ International/story?id=83003\&page $=1$ (accessed: 10 June 2018).

Cepin, M., and Bris, R. (ed.). (2017), Safety and Reliability. Theory and Applications, CRC Press, London.

COM/2011/670 final (2011), available at: https://eur-lex.europa.eu/legal-content/EN/TXT/HTML /?uri=CELEX:52011DC0670\&from=EN (accessed: 15 June 2018).

Coman-Kund, F. (2018), European Union Agencies as Global Actors: A Legal Study of the European Aviation Safety Agency, Frontex and Europol, Routledge, Oxon.

Convention on Civil Aviation ("Chicago Convention"), 7 December 1944, (1994), 15 U.N.T.S. 295, available at: http://www.refworld.org/docid/3ddca0dd4.html (accessed: 10 June 2018).

EUR-lex.europa.eu (2008), Regulation (EC) No. 216/2008 of the European Parliament and of the Council of 20 February 2008 on common rules in the field of civil aviation and establishing a European Aviation Safety Agency, and repealing Council Directive 91/670/EEC, Regulation 
(EC) No. 1592/2002 and Directive 2004/36/EC (Text with EEA relevance), L79/1, available at: https://eur-lex.europa.eu/legal-content/EN/TXT/HTML/?uri=CELEX:32008R0216\&fro $\mathrm{m}=\mathrm{EN}$ (accessed: 15 June 2018).

EUR-lex.europa.eu (2012), Commission Regulation (EU) No. 965/2012 of 5 October 2012 laying down technical requirements and administrative procedures related to air operations pursuant to Regulation (EC) No 216/2008 of the European Parliament and of the Council, available at: https://eur-lex.europa.eu/legal-content/EN/TXT/HTML/?uri=CELEX:02012R096520140217\&from=EN (accessed: 15 June 2018).

EUR-lex.europa.eu (2014), Regulation (EU) No. 376/2014 of the European Parliament and of the Council of 3 April 2014 on the reporting, analysis and follow-up of occurrences in civil aviation, amending Regulation (EU) No. 996/2010 of the European Parliament and of the Council and repealing Directive 2003/42/EC of the European Parliament and of the Council and Commission Regulations (EC) No. 1321/2007 and (EC) No 1330/2007 Text with EEA relevance, L122/18, available at: https://eurlex.europa.eu/legalcontent/EN/TXT/HTML/?uri $=$ CELEX:32014R0376\&from=EN (accessed: 15 June 2018).

Gill, G., and Shergill, G.S. (2004), "Perceptions of safety management and safety culture in the aviation industry in New Zealand", Journal of Air Transport Management, vol. 10, no. 4, pp. 231-237.

Goudou, P. (2009), "From vision to reality: The European Aviation Safety Programme", EASA European Aviation Safety Agency NEWS, no. 03.

Johnstone-Bryden, R. (2018), Concorde Pocket Manual, Osprey Publishing, Great Britain.

Klich, E. (2010), Bezpieczeństwo lotów w transporcie lotniczym, Wydawnictwo Naukowe Instytutu Technologii Eksploatacji - PIB, Radom.

Krajowy Program Bezpieczeństwa w Lotnictwie Cywilnym (2016), available at: https://mi.gov.pl/ files/0/1797358/KPBLC.pdf (accessed: 15 June 2018).

Kumaravadivelu, B. (2008), Cultural Globalization and Language Education, Yale University Press, New Haven-London.

Łuczak, K. (ed.). (2016), Zarządzanie bezpieczeństwem w lotnictwie cywilny, Śląska Biblioteka Cyfrowa, Katowice.

Miszczyk-Suchanek, M. (2017), „Implementacja konwencji o międzynarodowym lotnictwie cywilnym z 7 grudnia 1944 r.”, Ius Novum, no. 1.

Safety Management Manual (SMM) (2013), $3^{\text {rd }}$ ed. (e-book) International Civil Aviation Organization, available at: https://www.icao.int/safety/SafetyManagement/Documents/Doc.9859.3rd\%20 Edition.alltext.en.pdf (accessed: 10 June 2018).

Salas, E., and Maurino, D. (2010), Human Factors in Aviation, Elsevier, United States.

Williams, S.B. (2011), Getting Out Alive: 13 Deadly Scenarios and How Others Survived, Ulysses Press, Berkeley.

Yeun, R., Bates, P., and Murray, P. (2014), “Aviation safety management systems”, World Review of Intermodal Transportation Research, vol. 5, no. 2, pp. 168-196.

Żylicz, M. (2011), Prawo lotnicze międzynarodowe, europejskie i krajowe, Wolters Kluwer, Warszawa.
Legal Aspects of Safety

Management in Civil Aviation 